\title{
The ameliorative effect of Andrographis paniculata on $E$. coli-induced pathology in broilers
}

\author{
Suvarna R. Sonwane ${ }^{1}$, Ranjit S. Ingole ${ }^{1 *}$, Madhuri S. Hedau ${ }^{1}$, \\ Sunil W. Hajare ${ }^{2}$, and Maheshkumar V. Ingawale ${ }^{3}$ \\ ${ }^{1}$ Department of Veterinary Pathology, Post Graduate Institute of Veterinary and Animal Sciences, Akola, India \\ ${ }^{2}$ Department of Pharmacology and Toxicology, Post Graduate Institute of Veterinary and Animal Sciences, \\ Akola, India \\ ${ }^{3}$ Department of Animal Reproduction Gynecology and Obstetrics, Post Graduate Institute of Veterinary and \\ Animal Sciences, Akola, India
}

\begin{abstract}
SONWANE, S. R., R. S. INGOLE, M. S. HEDAU, S. W. HAJARE, M. V. INGAWALE: The ameliorative effect of Andrographis paniculata on $E$. coli-induced pathology in broilers. Vet. arhiv 89, 545-557, 2019.
\end{abstract}

\section{ABSTRACT}

The present investigation was carried out to evaluate the ameliorative effect of Andrographis paniculata during E. coli-induced pathology in broilers. Day-old broiler chicks $(\mathrm{n}=100)$ were randomly divided into four equal groups. Group I served as a negative control and was fed with a commercial diet. On day 8, the birds from groups II and IV were challenged with a single oral dose of $E$. coli broth culture $0.2 \mathrm{~mL}\left(1 \times 10^{9} \mathrm{cfu} /\right.$ $\mathrm{mL}$ ). Groups III and IV were fed with Andrographis paniculata $5 \mathrm{~g} / \mathrm{kg}$ of feed from day old to the end of the experiment. The total duration of the experiment was 35 days. On the $7^{\text {th }}, 21^{\text {st }}$ and $28^{\text {th }}$ day post infection (DPI) with $E$. coli, six birds from each group were randomly sacrificed and observed for gross and histopathogical observations. Group II birds showed ascites and thickened intestinal mucosa with cheesy material on the 28th and 35th DPI. Pathomorphological alterations, viz. congestion, hemorrhages, degenerations, necrosis, fibrinous exudates, edema, mononuclear cell and heterophil infiltration in the lung, liver, heart, kidneys and duodenum were observed in group II birds, along with depletion of the lymphoid cell population in the spleen. Pretreatment of Andrographis paniculata in the E. coli challenged group led to mild degenerative changes in all organs, indicating the putative protective effect of the plant during $E$. coli induced pathology in broilers. However, further, more elaborated study is required to calculate the dosage of Andrographis paniculata for use as an antibacterial agent in broiler feed.

Key words: amelioration; broilers; E. coli; Andrographis paniculata; pathology

\section{Introduction}

Avian colibacillosis caused by enterotoxigenic Escherichia coli is a serious infectious bacterial diseases in different types of chicken, leading to high morbidity, mortality, loss

\footnotetext{
*Corresponding author:
}

Dr. Ranjit Suresh Ingole, Head of Department of Veterinary Pathology, Post Graduate Institute of Veterinary and Animal Sciences, Akola 444104 (M.S.), India, E-mail: ingoleranjit@rediffmail.com 
of body weight, bad feed conversion ratio and a decrease in egg and meat production. $E$. coli are facultative anaerobic gram-negative rods and are normal inhabitants of a chicken's intestinal microflora. However, they may infect chickens, either as primary or a secondary pathogen, mainly associated with immunosuppression. Avian colibacillosis primarily affects broiler chickens between the ages of 4 and 6 weeks, and causes significant mortality in broilers. The mortality may reach up to 94 per cent in a severe outbreak of colibacillosis (McPEAKE et al., 2005 and BISWAS et al., 2006). Economic losses in broiler chickens due to colibacillosis amount to multimillion-dollar annual losses to the world's poultry industry (TAWAB et al., 2015). Control of E. coli in the poultry industry mainly depends on the use of certain antimicrobials, but excessive use of these antibiotics leads to anti-microbial resistance in food animals, as well as in human beings (MAHEJABIN et al., 2015). Hence, the problem of antibiotic resistance needs an urgent response. According to the Indian Health Ministry, the use of antibiotics in meat and egg producing chickens must be reduced, which ultimately restricts indiscriminate use of antibiotics in future.

Traditional herbal medicines have proved their advantages with their prophylactic and therapeutic effects, and in controlling the drug resistance and residue in livestock and poultry infectious diseases. Andrographis paniculata is reported to possess antihepatotoxic, antibiotic, anti-malarial, anti-hepatic, anti-thrombogenic, anti-inflammatory, anti-snake venom and antipyretic properties, besides its immunostimulant property (BURGOS et al., 2009). The components of Andrographis paniculata have shown therapeutic value because of its mechanism of action to expel the toxins from the body through enzyme induction. It is also used to treat gastrointestinal and upper respiratory tract infections, fever and a variety of other chronic and infectious diseases (CHOPRA et al., 1956). The plant also has the ability to modulate the cell surface hydrophobicity of enterohaemorrhagic E. coli, and shows high bacteriostatic and bactericidal activities (VORAVUTHIKUNCHAI and LIMSUVAN, 2006). Considering these facts, the present investigation was carried out to evaluate the ameliorative effect of Andrographis paniculata during $E$. coli induced pathology in broilers.

\section{Materials and methods}

Birds and diet. The present investigation was carried out in broiler chickens after receiving the necessary approval from the Institutional Animal Ethics Committee. Clinically healthy, day-old commercial broiler chicks $(n=100)$ of both sexes were procured from a commercial hatchery, and reared in a deep litter system. The chicks were fed with a standard commercial pre starter for 7 days, starter for 8-14 days and grower diet up to 35 days. All the experimental birds were maintained under identical management and hygienic conditions, and were kept under close observation during the entire period of the study. 
Bacterial strain and Andrographis paniculata leaf powder. The E. coli strain (MTCC No.723, bacteria H-10407 pathogenic, genetic stock, 078:K80:H11, CFA/I+ LT+ST+) was obtained from the Microbial Type Culture Collection and Gene Bank (MTCC), Chandigarh, India. The E. coli was grown on nutrient broth and the dose of E. coli $1 \times 10^{9}$ $\mathrm{cfu} / \mathrm{mL}$ concentration in broth culture was calculated by the standard method as described by HEDGE et al. (2009) and used for experimental induction of E. coli infection in broiler chickens. The dry leaf powder of Andrographis paniculata was procured from Nagarjun Medicinal Plants Garden, Dr. Panjabrao Deshmukh Krishi Vidyapeeth, Akola (Maharashtra) India.

Experimental design. After receiving the day-old broiler chicks $(\mathrm{n}=100)$, they were individually weighed and randomly divided into four equal groups. Each group comprised 25 birds. Group I served as the negative control group and was offered commercial feed. Group II served as the positive control group for $E$. coli infection. On day 8, each bird from group II was challenged with a single oral dose of $E$. coli broth culture $0.2 \mathrm{~mL}(1 \times$ $10^{9} \mathrm{cfu} / \mathrm{mL}$ ) to study the pathology of $E$. coli infection in broilers. Group III birds were fed with Andrographis paniculata $5 \mathrm{~g} / \mathrm{kg}$ of feed from one day old to the end of the experiment. Group IV birds were fed with Andrographis paniculata $5 \mathrm{~g} / \mathrm{kg}$ of feed from one day old, and on day 8 each bird from the group was challenged with a single oral dose of $E$. coli broth culture $0.2 \mathrm{~mL}\left(1 \times 10^{9} \mathrm{cfu} / \mathrm{mL}\right)$ to evaluate the ameliorative effect of Andrographis paniculata during E. coli induced pathology in broilers.

On the $7^{\text {th }}, 21^{\text {st }}$ and $28^{\text {th }}$ days post infection (DPI), six birds from each group were randomly selected and sacrificed. A detailed necropsy examination was performed on each bird and gross pathological observations were recorded. For histopathological examination, tissues of the lungs, liver, heart, kidneys, spleen and duodenum were collected in 10\% formal saline solution for histopathology. After fixation, tissues were processed for routine histopathological technique by the paraffin embedding method. Sections of 4-6 microns were cut on a rotary microtome (Make- Leika, Germany), stained with Haematoxylene and Eosin (H\&E) stain (LUNA, 1968) and were examined under a light microscope (Make- Magnus MLXi Plus Trinacular Microscope, Olympus Opto Systems India (P)Ltd.).

\section{Results}

Clinical observations. Only birds in group II treated with E. coli showed symptoms of lethargy, anorexia, sneezing, diarrhoea and crowding towards the corners of the shed after six days post infection. The signs were increasingly pronounced with the passing of days after the E. coli infection. However, groups I, III and IV did not show any clinical signs or behavioural changes of pathological significance. No mortality was recorded in any of the groups. 
Gross pathological observations. On necropsy examination, groups I and III did not reveal any gross pathological alterations, however, most of the birds in group II showed distended abdomens with ascites, characterized by the presence of an excessive amount of straw-coloured fluid in the abdominal cavity giving a pot-bellied appearance. Some of the birds showed hydropericardium on the $21^{\text {st }}$ and $28^{\text {th }}$ DPI. The intestines of group II birds, especially the duodenum, showed thickened mucosa, congestion and haemorrhages, with accumulation of yellowish cheesy material on the $7^{\text {th }}, 21^{\text {st }}$ and $28^{\text {th }}$ DPI when compared with the control group. The lungs of group II birds revealed congestion on the $21^{\text {st }}$ and $28^{\text {th }}$ DPI. Similar but milder lesions were also observed in group IV on the $21^{\text {st }}$ and $28^{\text {th }}$ DPI. No appreciable gross lesions were observed on the $7^{\text {th }}$ DPI in any of the groups.

\section{Histopathological observations}

Lungs. On microscopic examination, the lungs from group II birds revealed blood vessel congestion and haemorrhages with mild oedema on the $7^{\text {th }}$ DPI, while on the $21^{\text {st }}$ and $28^{\text {th }}$ DPI sections revealed congestion, oedema, haemorrhages filling the bronchiolar lamina, peribronchial lymphoid aggregation and a thickened bronchial wall. Some of the sections revealed heterophil infiltration with desquamation of the bronchiolar epithelium and serous to fibrinous exudates along with cellular debris on the serosal surface. However, the lesions observed in group II on the $28^{\text {th }}$ DPI were comparatively more severe when compared with the lesions on the $21^{\text {st }}$ and $7^{\text {th }}$ DPI (Fig. 1). Sections of lungs from group IV showed mild emphysema, mild to moderate congestion, peribronchial round cell infiltration and focal oedema with comparatively normal parenchyma on the $21^{\text {st }}$ and $28^{\text {th }}$ DPI. Groups I and III showed normal lung parenchyma on the $7^{\text {th }}, 21^{\text {st }}$ and $28^{\text {th }}$ DPI (Fig. 2).

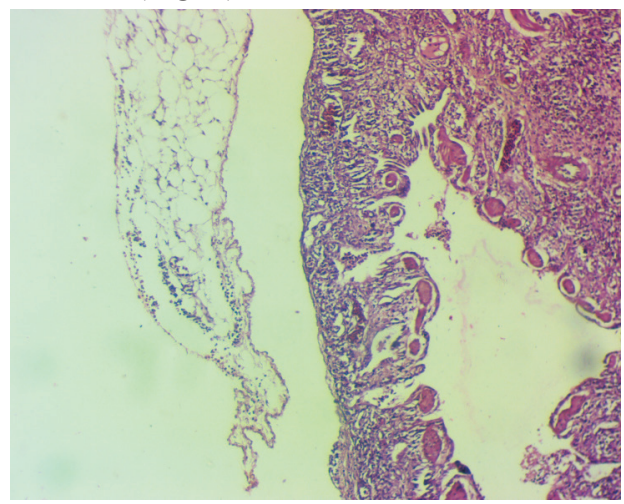

Fig. 1. Lung from T2 group showing serous to fibrinous exudates on serosal surface on $28^{\text {th }}$ DPI $(H \& E, \times 40)$

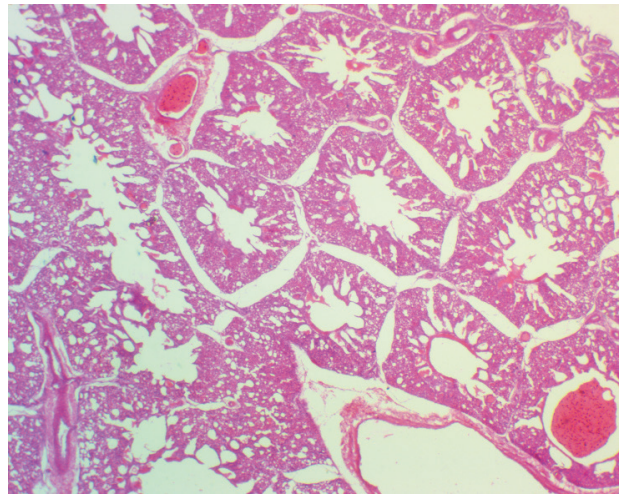

Fig. 2. Lung of T4 group showing bronchial haemorrhages and comparatively normal parenchyma on $21^{\text {st }}$ DPI $(H \& E, \times 100)$ 
Liver. Livers from group II revealed early degenerative changes on the $7^{\text {th }}$ DPI, while on the $21^{\text {st }}$ and $28^{\text {th }}$ DPI it showed congestion, haemorrhages, different stages of degenerative changes, viz. mild, or moderate to extensive vacuolar and granular changes in hepatocytes, fibrinous exudates in the sinusoidal spaces, focal necrosis, and prominent lymphoid aggregations in the parenchyma, as well as around the perivascular area. A few sections on the $28^{\text {th }}$ day showed prominent fatty changes and coagulative necrosis. The vacuolar and granular changes, along with mononuclear cell infiltration, were more prominent towards the pericapsular area, making the capsule thicker (Figs. 3 and 4). Group IV birds showed mild venous congestion, mild vacuolar and granular changes, mild lymphoid aggregation and focal areas of necrosis on the $21^{\text {st }}$ and $28^{\text {th }}$ DPI. The lesions observed were of less severity compared to group II (Fig. 5). Group I and III birds did not reveal any pathological lesions.

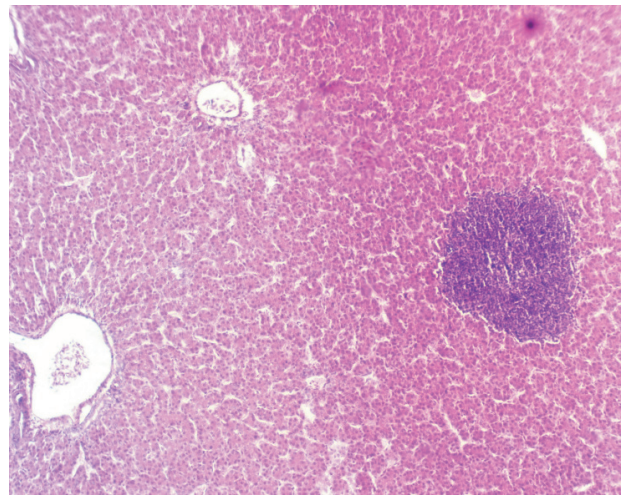

Fig. 3. Liver of T2 group bird showing prominent lymphoid cell aggregations in parenchyma on $28^{\text {th }}$ DPI $(\mathrm{H} \& \mathrm{E}, \times 100)$

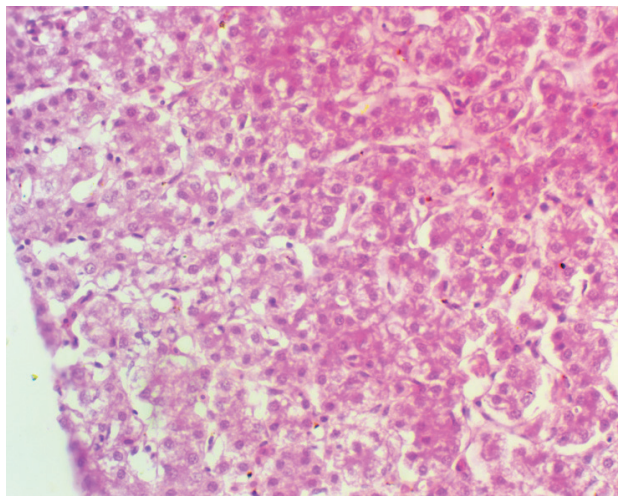

Fig. 4. Liver of T2 group bird showing extensive granular and vacuolar changes towards pericapsular area on $28^{\text {th }}$ DPI $(H \& E, \times 100)$

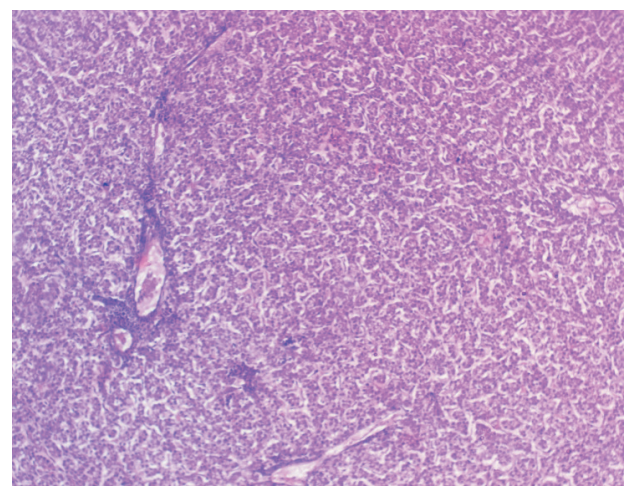

Fig. 5. Liver of T4 group showing mild to moderate vacuolar and granular changes, focal necrosis and lymphoid aggregation on $28^{\text {th }}$ DPI $(H \& E, \times 100)$ 
Heart. On $7^{\text {th }}$ DPI the hearts of group II birds showed mild vacuolar degeneration and haemorrhages in the myocardium, with mild separation of the cardiac muscle fibres. On the $21^{\text {st }}$ and $28^{\text {th }}$ DPI there was loss of cross striations and vacuolar degeneration in the epicardium and myocardium. Epicarditis was the most common serosal lesion in varying degrees, from destruction of the mesothelial cells to marked fibrinous exudates accumulated in the submesothelial tissue (Fig. 6). However, sections of hearts from group IV birds revealed mild haemorrhages on the $7^{\text {th }}$ DPI, while on the $21^{\text {st }}$ and $28^{\text {th }}$ DPI they showed mononuclear cell infiltration and mild vacuolar degenerative changes in the subepicardial areas, with comparatively normal architecture when compared with group II (Fig. 7). No lesions of pathological significance were observed in groups I and III.

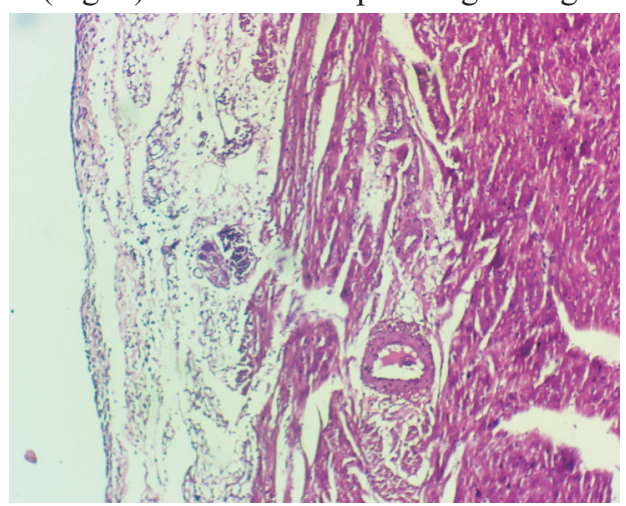

Fig. 6. Heart of T2 group bird showing marked fibrinous exudate accumulated in the submesothelial tissue on $28^{\text {th }}$ DPI $(\mathrm{H} \& \mathrm{E}, \times 100)$

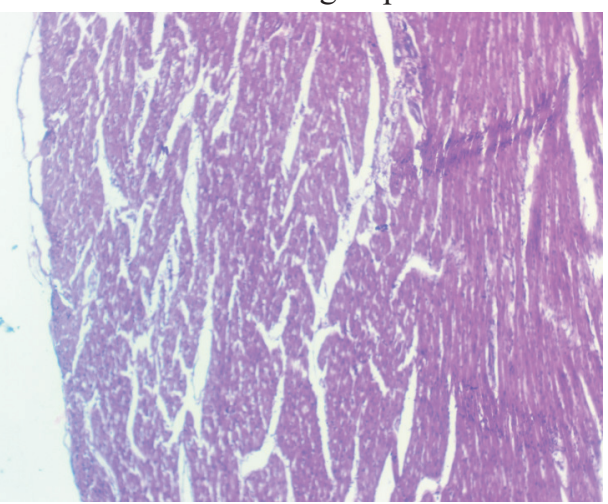

Fig. 7. Heart of T4 group bird showing mild vacuolar changes and comparatively normal histology on $28^{\text {th }}$ DPI $(H \& E, \times 100)$

Kidney. Microscopically, the sections of kidneys from groups I and III showed normal renal parenchyma, with mild granular and vacuolar changes in the tubular epithelium in one section only. Kidneys from group II birds showed mild blood vessel congestion and haemorrhages on the $7^{\text {th }}$ DPI, while on the $21^{\text {st }}$ and $28^{\text {th }}$ DPI they revealed congestion, haemorrhages with mononuclear cell and heterophils infiltration, the presence of a eosinophilic proteinaceous mass in the collecting tubules, desquamation of the tubular epithelium, and necrosis of tubules in some of them. Some of the sections showed glomerular degeneration with decreased cellularity (Fig. 8). The sections of kidneys from group IV revealed mild to moderate vacuolar and granular changes in the tubular epithelium on the $21^{\text {st }}$ and $28^{\text {th }}$ DPI. Some of the sections showed prominent glomerular degeneration (Fig. 9). 


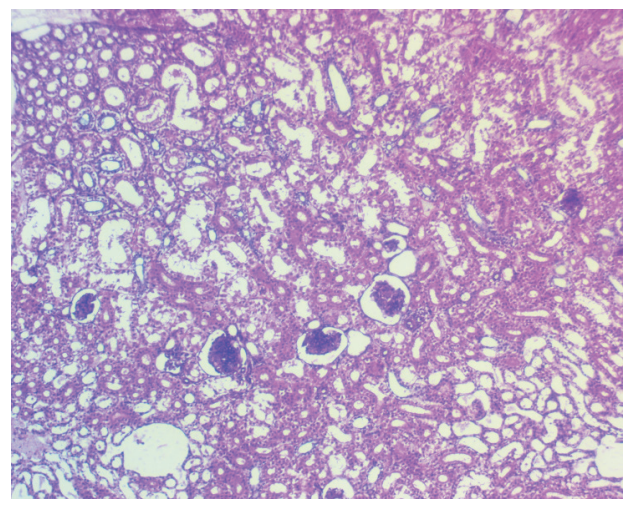

Fig. 8. Kidney of T2 group bird showing vacuolar degenerative changes in tubular and glomerular epithelium on $28^{\text {th }}$ DPI $(H \& E, \times 100)$

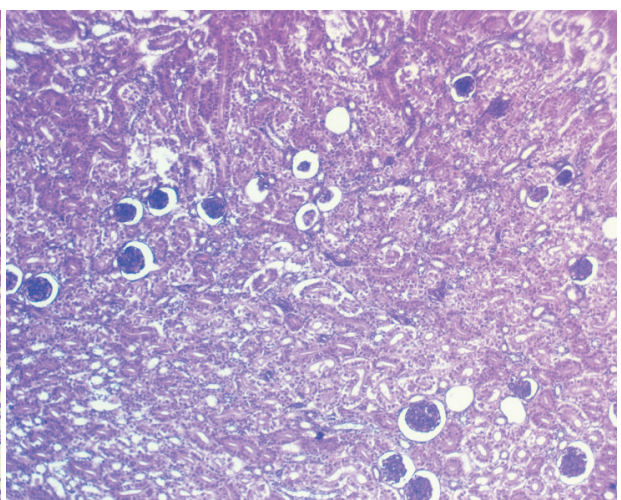

Fig. 9. Kidney of T4 group bird showing glomeular degeneration with increase urinary spaces on $28^{\text {th }}$ DPI $(\mathrm{H} \& \mathrm{E}, \times 100)$

Spleen. Spleens from group II birds showed comparatively normal splenic parenchyma, with mild depletion in lymphoid population on the $7^{\text {th }}$ DPI of the experiment. However, on the $21^{\text {st }}$ day of infection, there was moderate to extensive depletion in the lymphocyte population. On the $28^{\text {th }} \mathrm{DPI}$, sections revealed extensive depletion of the lymphocyte population, hyaline degeneration with necrosis of the lymphoid follicles in the germinal centre (Fig. 10). Also, sections of group IV birds showed mild to moderate depletion of the lymphoid population with comparatively normal splenic parenchyma on $21^{\text {st }}$ and $28^{\text {th }}$ day post infection. Spleens from group III birds showed normal spleen parenchyma as in the control group.

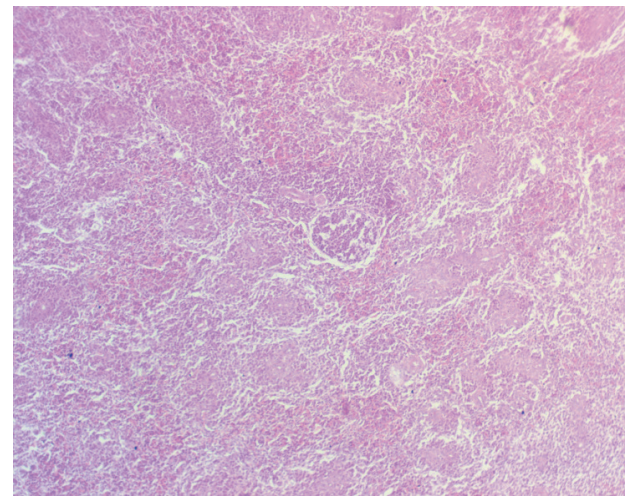

Fig. 10. Spleen of T2 group bird showing hyaline degenerative changes in follicle and focal necrosis on $28^{\text {th }}$ DPI $(H \& E, \times 100)$ 
Duodenum. Duodenums from group II birds showed normal length villi with mild degenerative changes on the $7^{\text {th }} \mathrm{DPI}$, while on the $21^{\text {st }} \mathrm{DPI}$, most of the duodenum showed slender narrow vill, desquamation and necrosis of the epithelium at the tip of the villi. On the $28^{\text {th }}$ DPI, sections revealed more prominent desquamation of the epithelium, thinning of the lamina propria, thickening of the muscularis mucosa and infiltration of mononuclear cells and heterophils in the submucosa. Some of them showed sloughing of the mucosa in the lumen (Fig. 11). However, group IV birds revealed similar changes to those of group II, but they were of less severity, including desquamation of the epithelium at the tip of the villi and infiltration of heterphils with comparatively normal finger-like structures on the $21^{\text {st }}$ and $28^{\text {th }}$ DPI sections (Fig. 12).

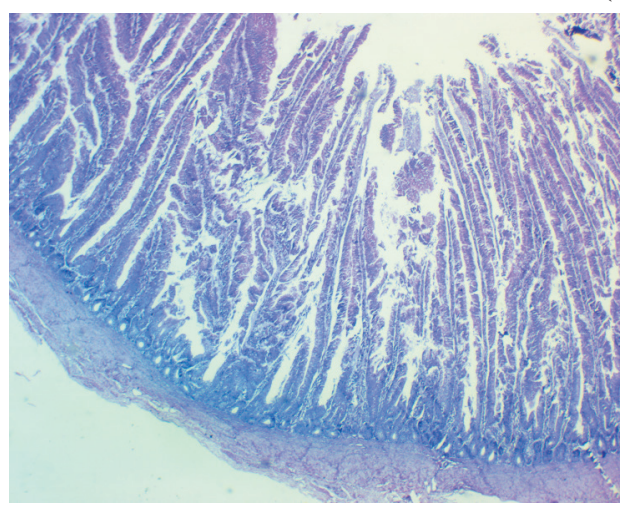

Fig. 11. Duodenum of T2 group birds showing prominent desquamation of epithelium, and infiltration of leucocytes on $28^{\text {th }}$ DPI $(H \& E, \times 40)$

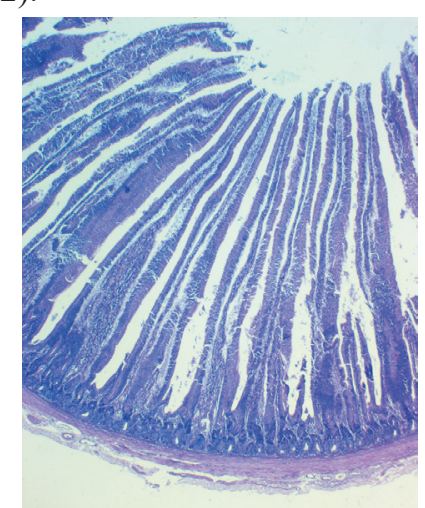

Fig. 12. Duodenum of T4 group birds showing comparatively normal finger like structure of villi on $28^{\text {th }}$ DPI $(H \& E, \times 40)$

\section{Discussion}

The present findings of diarrhoea and ascitis in E. coli infection were also reported by ZAKI et al. (2012). AKBAR et al. (2009) confirmed the present findings of lethargy, anorexia, diarrhoea and crowding towards the corners of the shed. Similar clinical symptoms were observed in E. coli infected birds by earlier authors (ALLAM et al., 2014; HE et al., 2014; HAQ et al., 2015). HEGAZY et al. (2015) suggested that $E$. coli causes digestive and respiratory tract infections which lead to diarrhoea, rales, sneezing and depression after 6 days post-infection. Various studies have reported the therapeutic value of Andrographis paniculata in acute bacillary dysentery and gastroenteritis, showing its protective effects (TIPAKORN, 2002) which might be the reason for the reduced severity of the clinical signs in group IV. HE et al. (2014) investigated the therapeutic effects of a Chinese medicine, containing Andrographis paniculata as one of its contents, on Avian Pathogenic Escherichia coli (APEC)-infected chickens, and observed the infected 
chicken's improved health status and a decrease in the incidence of pericarditis and perihepatitis.

The gross pathological lesions observed in group II were more or less in agreement with earlier authors (DADHEECH and VYAS, 2013; GHANY and ISMAIL, 2014) in E. coli-infected birds, and were more pronounced on the $28^{\text {th }}$ DPI compared to the $21^{\text {st }}$ DPI. In addition to the present findings, the literature revealed perihepatitis, pericarditis, cloudy air sacs, fibrinous airsacculitis, fibrinous bronchopneumonia along with congestion in $E$. coli infected broilers (HAQ et al., 2015; HEGAZY et al., 2015; AZEEM et al., 2016) which might be due to changes in the route of infection or the dose of $E$. coli infection. Variations in the strain of E. coli might be another reason. KUMAR et al. (2004) observed the formation of a thin fibrin layer over the heart and liver on the $1^{\text {st }}$ DPI, which became much thicker on the $7^{\text {th }}$ DPI using the peritoneal route to induce infection.

Changes such as congestion, haemorrhages, degeneration, necrosis and heterophilic infiltration might be due to the response and reaction in the form of detoxification and excretion of enterotoxins released by E. coli infection. TONU et al. (2011) recorded infiltration of heterophils, macrophages and lymphocytes in the wall of the bronchus, as well as in the peribronchial alveoli, and this is in agreement with the present findings. AZEEM et al. (2016) observed mononuclear cell infiltration, a fibrinous layer and atrophy of adjoining hepatic cords, due to the greatly distended and congested sinusoids and thickening of the capsule due to invasion of mononuclear cells in the liver. Lesions observed in the hearts were more or less similar to the lesions observed by TRUSCOTT et al. (1974), NAKAMURMA et al. (1985) and AKBAR (2011) in E. coli infections. Lesions observed in the spleen were in agreement with TRUSCOTT et al. (1974), including the small area of coagulative necrosis around the germinal follicle and necrosis of the outer lymphoid areas. Pathomorphological alterations, viz. congestion, haemorrhages, degenerations, fibrinous exudates, oedema, focal areas of necrosis, mononuclear cell and heterophil infiltration in the lungs, liver, heart, kidneys, spleen and duodenum observed in the present study are consistent with the findings observed by previous researchers (TRUSCOTT et al.,1974; KUMAR et al., 2004; DUTTA et al., 2013; KUMAR et al., 2013).

The prominent findings of congestion, haemorrhages, fibrinous exudate, lymphoid aggregation and infiltration of heterophils in the lungs, liver, heart, kidney and duodenum observed during the present investigation may be correlated with ROMERO et al. (2015), who reported that $E$. coli inflammation causes a displacement of leukocytes and plasma molecules to the site of infection, and may be observed as a main feature of $E$. coli inflammation.

Andrographolide reduces the pathogenicity of APEC-078 in chicken type II pneumocytes by interfering with the bacterial QS and decreasing virulence (ZHANG 
et al., 2014), which might be the reason for the comparatively normal histopathological observations recorded in group IV on the $21^{\text {st }}$ and $28^{\text {th }}$ DPI compared to group II birds. Pretreatment with Andrographis paniculata prevented a significant increase in triglycerides, cholesterol, LDL, and protein oxidation, increased antioxidant enzyme and caused a putative protective effect by managing the oxidative damage at cellular level (NEOGY et al., 2008; SIVAKUMAR and RAJESHKUMAR (2015)). This might be the reason for the comparatively normal histoarchitecture of the lungs, liver, heart, kidneys, spleen and intestines in group IV birds. OJHA et al. (2012) concluded that the two main deterpenoids isolated from Andrographis paniculata were 14-deoxyandrographolide and 14-deoxy-11, 12-didehydrographolide, and could be the reason for the cardio protective effect due to their antioxidant, free radical scavenging and anti-lipid per oxidation properties.

The results therefore indicated the ameliorative effect of Andrographis paniculata during E. coli induced pathology in broilers. However further elaborated study is required to calculate the actual dose of dried leaf powder of Andrographis paniculata for use as an antibacterial agent in broiler feed, which will ultimately restrict indiscriminate use of antibiotics for the prevention and treatment of $E$. coli infection of broilers birds in future.

\section{Acknowledgements}

The authors are thankful to the Associate Dean of the Post-Graduate Institute of Veterinary and Animal Sciences, Akola, for providing the required facilities for conducting this research work.

\section{References}

AKBAR, S. (2011): Andrographis paniculata: A review of pharmacological activities and clinical effects. Altern. Med. Rev. 16, 66-77.

AKBAR, H., M. KHAN, A. ALI KHAN, M. ALI KHAN, M. SHUAIB, S. F. AKBAR, S. MANZOOR, IRSHAD-UR-REHMAN, S. AHMAD, L. ALI, R. KHALID, M. IDREES (2009): Comparative efficacy of doxycycline and flumequine against experimentally induced colibacillosis in broiler chicks. Journal of Veterinary Medicine, Animal Health 1, 17-22.

DOI: $10.1093 / \mathrm{gmo} / 9781561592630$.article.14962

ALLAM, H. H., S. EMAN, A. E. HAMID, H. SALAH, R. M. RASHIDY, E. M. ADEL (2014): Effect of organic acids and probiotic on broiler performance, some blood parameters and control of E. coli. Zag. Vet. J. 42, 108-117.

AZEEM, R. M., A. ASLAM, M. REHMAN, T. YAQUB (2016): Pathological investigation and molecular detection of avian pathogenic E. coli serogroups in broiler birds. J. Vet. Sci. Technol. $7,373$.

DOI: $10.4172 / 2157-7579.1000373$ 
S. R. Sonwane et al.: Ameliorative effect of Andrographis paniculata on E. coli induced pathology in broilers

BISWAS, P. K., G. M. N. UDDIN, H. BARUA, K. ROY, D. BISWAS, A. AHAD N. C. DEBNATH (2006): Causes of loss of Sonali chickens on smallholder households in Bangladesh. Prev. Vet. Med. 76, 185-195.

DOI: 10.1016/j.prevetmed.2006.05.001

BURgos, R. A., J. L. HANCKE, J. C. BERTOGLiO, V. AgUiRRE, S. ARRIAGAdA, M. CALVO, D. CACERE (2009): Efficacy of an Andrographis paniculata composition for the relief of rheumatoid arthritis symptoms: A prospective randomized placebo-controlled trial. Clin. Rheumatol. 28, 931-946.

DOI: $10.1007 / \mathrm{s} 10067-009-1180-5$

CHOPRA, R. N., S. L. NAYER, I. C. CHOPRA (1956): Glossary of Indian Medicinal plants, NISCO, CSIR, New Delhi, India, 18.

DADHEECH, T., R. VYAS (2013): Clinical and gross-pathological diagnosis of infectious bacterial diseases of layer chickens in Ajmer region of Rajasthan. Res. J. Pharma. Biological \& Chemical Sciences, 4, 1537.

DUTTA, P., M. K. BORAH, R. SARMAH, R. GANGIL (2013): Isolation, histopathology and antibiogram of Escherichia coli from pigeons (Columba livia). Vet. World 6, 91-94.

DOI: 10.5455/VETWORLD.2013.91-94

GHANY, A. W., M. ISMAIL (2014): Tackling experimental colisepticaemia in broiler chickens using phytobiotic essential oils and antibiotic alone or in combination. Iran J. Vet. Res. 15, 110-115.

HAQ, K. U., A. A. KHAN, S. ULLAH, G. NABI (2015): Comparative efficacy of Norfloxacin, Clarithromycin and Cefpodoxime against experimentally induced colibacillosis in pigeons. American-Eurasian Journal of Toxicological Sciences, 7, 72-82.

HE, C. L., B. D. FU, P. F. YI, X. B. WEI, Z. Q. YIN, C. LV, W. ZHANG, X. M. HAN, X. L. CUN (2014): Effectiveness of Xiang-Qi-Tang against avian pathogenic Escherichia coli. Pak. Vet. J. 34, 127-129.

HEDGE, A., G. K. BHAT, S. MALLYA (2009). Effect of stress on production of heat labile enterotoxin by E. coli. Indian J. Med. Microbiol. 27, 325-328.

DOI: $10.4103 / 0255-0857.55446$

HEGAZY, A. M., O. HASSANIN, G. F. ISMAEIL (2015): An experimental co-infection of Broilers with local isolates of Ornithobacterium rhinotracheale and E. coli. Zagazig Vet. J. 43, 82-94.

DOI: $10.21608 /$ zvjz.2015.28445

KUMAR, A., D. BHALERAO, R. P. GUPTA, M. KUMARI (2013): pathological studies on natural cases of avian collibacillosis in Haryana state. Haryana Vet. 52, 118-120.

DOI: $10.1080 / 03079450410001724021$

KUMAR, A., N. JINDAL, C. L. SHUKLA, R. K. ASRANI, D. R. LEDOUX, R. E. GEORGE (2004): Pathological changes in broiler chickens fed ochratoxin A and inoculated with Escherichia coli. Avian Pathol. 33, 413-417. 
S. R. Sonwane et al.: Ameliorative effect of Andrographis paniculata on E. coli induced pathology in broilers

LUNA, L. G. (1968): Manual of Histopathological Staining Methods of the Armed Forces Institute of Pathology, $3^{\text {rd }}$ ed. New York, McGraw Hill Book Co.

MAHEJABIN, N., M. MOSTOFA, F. AKTER, S. DAS, M. ALAM (2015): Effects of Neem, turmeric and papaya leaf extract mixture on growth performance of broilers. Int. J. Nat. Soc. Sci. 2, 17-21.

McPEAKE, S. J., J. A. SMYTH, H. J. BALL (2005): Characterisation of avian pathogenic Escherichia coli (APEC) associated with coli septicaemia compared to faecal isolates from healthy birds. Vet. Microbiol. 110, 245-53.

DOI: 10.1016/j.vetmic.2005.08.001

NAKAMURMA, K., Y. MAEDA, I. MADAA, N. K. SATO (1985): Pathology of spontaneous colibacillosis in a broiler flock. Poultry Disease Laboratory, National Institute of Animal. Vet. Pathol. 22, 592-597.

DOI: $10.1177 / 030098588502200614$

NEOGY, S., S. DAS, S. K. MAHAPATRA, N. MANDAL, S. ROY (2008): Amelioratory effect of Andrographis paniculata Nees on liver, kidney, heart, lung and spleen during nicotine induced oxidative stress. Environ. Toxicol. Pharmacol, 25, 321-328.

DOI: $10.1016 /$ j.etap.2007.10.034

OJHA, S., S. BHARTI, M. GOLECHNA, A. K. SHARMA, N. RANI, S. KUMARI, D. S. ARYA (2012): Andrographis paniculata extract protect against isoproterenol unduced myocardial injury by mitrigating cardiac dysfunction and oxidative injury in rats. Acta Ploniae Pharmaceutica Drug Res. 69, 269-278.

ROMERO, R. T., T. S. DOS SANTOS, F. P. DE MATO, A. FRANCIOSI, N. F. CAMPOIS, J. P. SARMIENTO, G. NAKAZATO, K. D. GUALTIERI, T. G. CAMPOIS (2015): Study of cell migration in intraperitoneal infection by Escherichia coli in Mice Swiss. Front. Immunol. Conference Abstract: IMMUNOCOLOMBIA 2015 - 11 $1^{\text {th }}$ Congress of the Latin American Association of Immunology, p. 100.

SIVAKUMAR, V., S. RAJESHKUMAR (2015): Protective effect of Andrographis paniculata on hyperglycemic mediated oxidative damage in renal tissues of diabetic rats. J. Psychopharmacol. 4, 287-294.

TAWAB, A. A., A. A. KOMY, E. E. KHALID, I. EKHNAWY, A. T. TALAIE (2015): Effect of fosfomycin on E. coli $\mathrm{O} 78$ isolated from broiler chickens in-vitro and in vivo. BVMJ. 28, 294-300.

TIPAKORN, N. (2002): Effect of Andrographis paniculata (burm F.) Nees on performance, mortality and coccidiosis in broiler chickens. Doctoral Dissertation. Georg-August-University. Gottingen, Germany.

TONU, N. S., M. A. SUFIAN, S. SARKER, M. M. KAMAL, M. H. RAHMAN, M. M. HOSSAIN (2011): Pathological study on colibacillosis in chickens and detection of Escherichia coli by PCR. Bangl. J. Vet. Med. 9, 17- 25.

DOI: $10.3329 /$ bjvm.v9i1.11205 
S. R. Sonwane et al.: Ameliorative effect of Andrographis paniculata on E. coli induced pathology in broilers

TRUSCOTT, R. B., A. J. LOPEZ, J. R. PETTIT (1974): Studies of Escherichia coli infection in chickens. Can. J. Comp. Med. 38, 160-167.

VORAVUTHIKUNCHAI, S. P., S. J. LIMSUVAN (2006): Medicinal plant extract as anti Eschershia coli 0157:H7 and their effect on bacterial cell aggregation. Food Prot. 69, 23362341.

DOI: $10.4315 / 0362-028 x-69.10 .2336$

ZAKI, M. S., O. FAWZY, M. H. OSFOR (2012): Effect of E. coli 0H157 on Baladi broiler chicken and some biochemical studies. Life Sci. J. 9, 91-94.

ZHANG, L., G. T. CAO, X. F. ZENG, L. ZHOU, P. R. FERKET, Y. P. XIAO, A. G. CHEN, C. M. YANG (2014): Effects of Clostridium butyricum on growth performance, immune function and cecal microflora in broiler chickens challenged with Escherichia coli K88. Poultry Sci. 93, 46-53.

DOI: $10.3382 /$ ps.2013-03412

Received: 26 February 2018

Accepted: 27 June 2019

SONWANE, S. R., R. S. INGOLE, M. S. HEDAU, S. W. HAJARE, M. V. INGAWALE: Ublažavajući učinak biljke Andrographis paniculata na promjene u brojlera uzrokovane bakterijom $E$. coli. Vet. arhiv 89, 545-557, 2019.

SAŽETAK

Istraživanje je provedeno kako bi se procijenio ublažavajući učinak biljke Kineski andrografis (Andrographis paniculata) na patološke procese u brojlera uzrokovane bakterijom E. coli. Jednodnevni pilići $(\mathrm{n}=100)$ slučajnim su odabirom podijeljeni u četiri jednake skupine. Prva je skupina poslužila kao negativna kontrola i hranjena je komercijalnom hranom. Osmi dan pilićima iz druge i četvrte skupine peroralno je dana jednokratna doza $E$. coli bujona u količini od $0,2 \mathrm{~mL}\left(1 \times 10^{9} \mathrm{cfu} / \mathrm{mL}\right)$. Treća i četvrta skupina hranjene su biljkom Andrographis paniculata u količini od $5 \mathrm{~g} / \mathrm{kg}$ hrane od početka do kraja pokusa. Istraživanje je trajalo 35 dana. Sedmi, 21. i 28. dan nakon zaražavanja bakterijom $E$. coli po šest pilića iz svake skupine nasumce je usmrćeno te su promatrane makroskopske i patohistološke promjene. U drugoj je skupini uočen ascites i zadebljanje crijevne sluznice sa sirastim naslagama 28. i 35. dan poslije zaražavanja. U toj su skupini promatrane patomorfološke promjene poput kongestije, krvarenja, degeneracije, nekroze, fibrinskog eksudata, edema, infiltracije pluća, jetre, srca, bubrega i dvanaesnika mononuklearnim i heterofilnim stanicama, uz depleciju limfoidnih stanica u slezeni. Dodavanje biljke Andrographis paniculata skupini zaraženoj bakterijom E. coli utjecalo je na pojavu blažih degenerativnih promjena u svim organima, što upućuje na zaštitni učinak biljke tijekom izlaganja brojlera bakteriji E. coli. Potrebna su daljnja istraživanja kako bi se izračunala doza biljke Andrographis paniculata kao antibakterijskog dodatka/lijeka u prehrani brojlera.

Ključne riječi: ublažavajući učinak; brojleri; E. coli; Andrographis paniculata; patološke promjene 
